notes should be minimal and charts or tables avoided. These reports may be preliminary descriptions of programs or research to be published formally at a later date in library literature (e.g., "Online Searching and Chemistry Students at Knox," February 1982).

b. Reports on a recent conference or workshop of interest to academic or research librarians (e.g., "Second International Conference on User Education," November 1981).

c. Reasoned and informed speculation or comment on a relevant topic, especially if solicited by the editor or an official ACRL group (e.g., "Enemies of Books," October 1981).

d. State-of-the-art reports on a relevant topic (e.g. , "Education for Community College Librarianship," September 1981).

e. Standards, guidelines, or recommendations of an ACRL committee or other official ACRL group (e.g., "Guidelines for Two-Year College Learning Resources Programs," January \& February 1982).

\section{Manuscript}

Authors should submit two copies, doublespaced, following either the University of Chicago's Manual of Style or Turabian.

\section{Requests for Donations}

$C$ \& RL News may occasionally print requests for the donation of books or materials to libraries, especially foreign libraries, which have suffered extensive loss through fire, hurricane, or other natural disaster. Other libraries soliciting contributions for other reasons will be referred to the rates for classified advertising in CdRL News.

Editor's Note: These guidelines were adopted by the C\&RL News Editorial Board at the Midwinter meeting on January 25, 1982. The board consists of Jay K. Lucker (chair), Linda Beaupré, Catherine Reichert, Patricia Glass Schuman, Jean M. Whalen, and Hiram L. Davis.

\title{
Guidelines for Extended Campus Library Services
}

\section{FOREWORD}

In January 1980, the ACRL Standards and Accreditation Committee undertook the review of the 13-year-old "Guidelines for Library Services to Extension Students" to determine if a revision of these guidelines was appropriate. Membership of the Committee at the time this project was first discussed included Marjorie C. Dennin, director of learning resources, Annandale Campus, Northern Virginia Community College; James T. Dodson, (chair), director, University of Texas at Dallas Library; Jane G. Flener, associate director, University of Michigan Libraries; Peter C. Haskell, director, Franklin and Marshall College Library; George V. Hodowanec, director of the library, Emporia State University; Jay K. Lucker, director of libraries, Massachusetts Institute of Technology; Elizabeth M. Salzer, librarian, J. Henry Meyer Memorial Library of Stanford University Libraries; and Barbara J. Williams Jenkins, director, South Carolina State College Library. Since June 1980, the following membership changes have occurred: Patricia Ann Sacks, director of libraries, Muhlenberg and Cedar Crest Colleges, replaced James T. Dodson as chair of the committee, and Irene B. Hoadley, director of libraries, Texas A \& M University, replaced Jane Flener.

Following a survey of the ACRL membership, a draft of proposed revised guidelines for library services to extension students was prepared and further responses were solicited. Hearings were held during the 1981 ALA Midwinter Conference. The published draft was revised by the Committee to reflect testimony and written responses, and approved by the ACRL Board on January 26.

\section{INTRODUCTION}

Changing patterns within higher education during the last few decades have placed broader demands on library resources and services. Four factors have necessitated the review of library services to extension students: the growing importance of continuing education and off-campus programs; the open admissions policy at many colleges and universities and the corresponding change in the student body; proliferation of academic programs and an increase in the number of locations at which they are offered; and, new technological advancements and the increase in the complexity and quantity of informational resources. These exogenous factors have called for a review of library services on the main campuses and have necessitated the revision of the guidelines of library service for continuing education and off campus services.

"Guidelines for Extended Campus Library Services" supersede the 1957 "Guidelines for Library Services to Extension Students." The change in 
title was made to account for both a wider range of library services and an expanded concept of what should be included in supporting extended campus academic programs. The revised guidelines apply to library services for institutional programs offered on campus as well as off campus, courses taken for credit or on a noncredit basis, programs pursued on a full time basis or as part of a continuing education program, courses attended in person or by means of electronic transmission, or any other nontraditional program which extends beyond the usual concept of higher education.

Because extended campus programs are characterized by a high degree of diversity and subject to rapid change, these guidelines provide a framework for developing extended campus library services without being prescriptive or normative. The six major sections-Planning, Finances, Personnel, Facilities, Resources, and Services-articulate the necessary conditions for adequate services and reflect standard management practices.

\section{DEFINITIONS}

The phrase "extended campus library services" covers library programs designed for nontraditional and/or continuing education students and faculty. The courses may be credit or noncredit, the students matriculated or nonmatriculated, full-time or part-time, and the classes taught at a main campus, branch campus, or off-campus location.

\section{ASSUMPTIONS}

1) The academic library is primarily responsible for identifying, developing, and providing resources and services which address the information needs of students and faculty in extended campus programs.

2) The library's parent institution is responsible for providing support which addresses the information needs of its extended campus programs.

3) Effective services for extended campus communities may differ from established practices. The requirements of the instructional program rather than tradition should guide the library's responses to defined needs.

\section{Planning}

To identify the information needs of students and faculty in extended campus programs, and arrange to meet these needs, the library should:

1) Assess the needs of its extended campus community for library resources, services and facilities.

2) Prepare a written profile of the extended community's information needs.

3) Develop a written statement of objectives, including immediate and long-range goals, addressing the needs and outlining methods by which progress toward the attainment of these goals can be measured.
4) Involve appropriate extended academic community representatives, including the faculty, in the formation of the objectives and the regular evaluation of their achievement.

\section{FinanCES}

The library should provide continuing financial support for addressing the needs of the extended campus community. This financing should be:

1) Related to the formally-defined needs and demands of the instructional program.

2) Allocated on a schedule matching the parent institution's budgeting cycle.

3) Identified within the library's budget request and expenditure reporting statements.

4) Accommodated to contractual arrangements involving external agencies, including affiliated, but independently-supported libraries.

\section{PERSONNEL}

Qualified library personnel should be employed to plan, implement, and evaluate library programs addressing the needs of extended campus students and faculty. This requires:

1) Persons with the capacity and skills to identify needs and respond to them flexibly and creatively.

2) sufficient numbers to attain defined goals and objectives.

3) Classification, status, and salary scales for extended campus library staff that are equivalent to those provided for other library employees.

\section{FACILITIES}

The library should provide facilities and equipment sufficient in size, number, and scope to attain the objectives of the extended campus programs. Examples of suitable arrangements include:

1) Contracts with a non-affiliated library to provide resources and/or services.

2) An off-site library office for consultations, access to ready reference collections, online data base searching and interlibrary loan services.

3) Telephone consultation services and/or pairing of students and faculty with a staff member who will respond to their needs.

4) A branch library when a sufficient number of classes are offered at an off-site location.

\section{ResourCes}

Access to library materials in sufficient number, scope, and format (print and non-print) should be provided to:

1) Accommodate the students' needs in fullfilling course assignments, including required and assigned readings and research papers.

2) Accommodate teaching needs, including the preparation of instructional materials and the application of various modes of instruction.

Programs granting associate degrees should provide access to collections which meet the 
"Guidelines for Two-Year College Learning Resources Programs" and the "Statement on Quantitative Standards." Programs granting baccalaureate or master's degrees should provide access to collections which meet the standards defined by the "Standards for College Libraries." Programs offering doctorate degrees should provide access to collections which meet the standards defined by the "Standards for University Libraries."

\section{SERVICES}

The services offered students and faculty in extended campus programs should be designed to meet effectively a wide range of different information and bibliographic needs. Examples of arrangements which may meet these needs include:

1) Reference assistance.

2) Electronic transmission of information.

3) Computer-assisted bibliographic and information services.

4) Instruction in bibliography and the use of information tools and equipment.

5) Assistance with non-print media and equipment.

6) Reciprocal borrowing referrals and interlibrary loan services.

\section{LIBRARY SERVICE FOR NONCAMPUS STUDENTS}

The off-campus site has played an important role in attracting adults to college. While these students appreciate the convenience of the sites, they can be frustrated by the lack of certain academic support services, particularly those of the library.

St. Joseph's College, New York, faced this problem at its off-campus sites in the Levittown area, located in Nassau County approximately one-half hour from its Branch Campus in Suffolk County. Responding to its clear obligation to provide adequate library resources for these students, St. Joseph's turned to the Levittown Public Library for help.

The "Guidelines for Library Services to Extension/Noncampus Students" (CURL News, October 1980, and revised in this issue) gave direction and support for the proposal made to the Levittown Public Library.

This library was ideal for two reasons: it was close to the sites and it had an impressive collection in the academic program areas offered at those sites. Open to the cooperative venture, the Levittown Public Library signed an agreement with the college in January, 1981. According to this plan, St. Joseph's students who live in Nas- sau County and possess direct access cards are assured an orientation to the resources, reference services, and borrowing privileges of the library. In return, St. Joseph's purchases books and journals to enrich the health sciences collection at Levittown. The selection of materials to be added is made by St. Joseph's faculty after a careful analysis of the collection.

The provisions of the agreement are as follows:

1) St. Joseph's College will initially expend approximately $\$ 2,500$ for books and subscriptions to journals relating to the college's Community Health and Health Administration programs. Additional expenditures in subsequent years will be made to enrich the collection.

2) The materials so funded will belong to St. Joseph's College. Should the college terminate the agreement and elect to withdraw the materials deposited at the public library, the library will make a reasonable effort to return all library materials, but assumes no responsibility for replacement of missing materials. Journals would be retained by the Levittown Public Library while listed in the current Union List of Serials for Nassau and Suffolk.

3) These materials so funded will be ordered and processed by the public library through the Nassau Library System. The processing cost assessed by the Nassau Library System for these materials will be assumed by St. Joseph's College.

4) The books and journals will be intershelved with the total library collection and will circulate according to established library procedures.

5) Access to these materials will be through the card catalog and periodical listing.

6) Students who are not residents of the Levittown Library District but who are eligible for a card from the Nassau County Public Library will use their library cards after having them stamped for direct access at their home library. These students will have borrowing privileges normally extended to Direct Access patrons.

7) Reference service will be available to the students.

8) St. Joseph's College students will be expected to abide by all the rules and regulations of the Levittown Public Library.

9) The college will instruct its students in the procedures and regulations in force at the public library as well as the specifics of this agreement.

10) This agreement will be in force for two years with automatic, annual, one-year renewals, subject to the option of either party's notifying the other in writing of the intention to terminate the agreement 60 days prior to the annual renewal date. - Submitted by Thomas G. Travis and S. Dorothy Watson, St. Joseph's College; P. W. Martin and Ceil Roberts, Levittown Public Library.

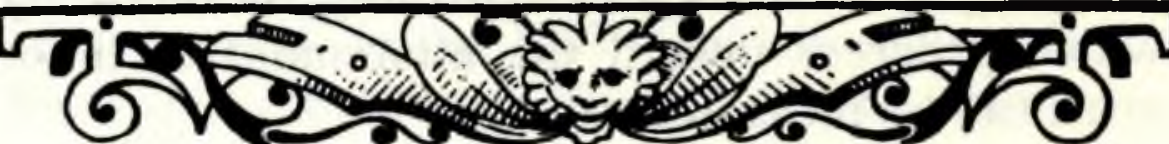




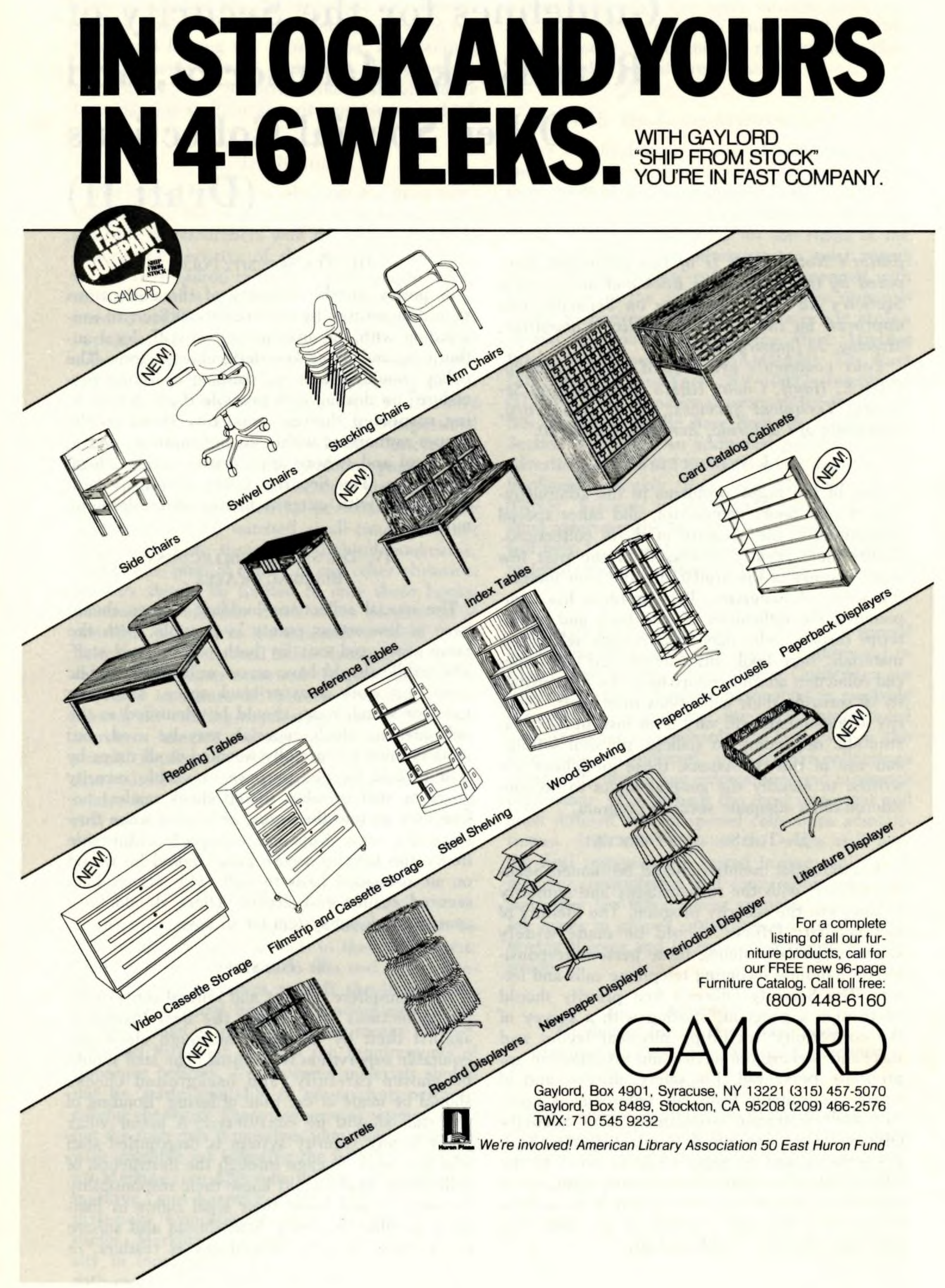

